\title{
Improving Indonesian Language Learning Results Concerning Explanation Text Through Discussion Method in Class VI SD Negeri Danasri Kidul 02
}

\author{
Fatimah \\ SD Negeri Danasri Kidul 02 \\ fatimahtok88@gmail.com
}

\section{Article History}

accepted 14/11/2020

approved 21/11/2020

published 26/11/2020

\begin{abstract}
The purpose of this study was to determine the effect of using discussion methods on student learning outcomes. This research was conducted through a cycle assessment process consisting of four stages (planning, implementing, observing, and reflecting) in three cycles of learning improvement. Cycle I was carried out on Monday, October 26, 2020, cycle II was held on Monday November 2, 2020 and cycle III was carried out on Friday November 20, 2020. From the results of the analysis of the conclusions obtained from this study: Use of the discussion method in Indonesian language learning The subject matter of explanatory text is proven to improve student learning outcomes, the average formative test in the initial conditions is 55, in cycle I it increases to 74.33, in cycle II it increases again to 82.5 and in cycle III it increases again to 88.63 . Completeness of student learning has increased from the initial conditions $33.33 \%$ increased in cycle I to 50\%, increased again in cycle II to 66.67 and increased again in cycle III to $100 \%$.
\end{abstract}

Keywords: Discussion, Indonesian, learning outcomes.

\begin{abstract}
Abstrak
Tujuan penelitian ini untuk mengetahui pengaruh penggunaan metode diskusi terhadap hasil belajar siswa. Penelitian ini dilakukan melalui proses pengkajian berdaur yang terdiri dari empat tahapan (perencanaan, pelaksanaan, pengamatan, dan refleksi) dalam tiga siklus perbaikan pembelajaran. Siklus I dilaksanakan pada hari Senin tanggal 26 Oktober 2020, siklus II dilaksanakan pada hari Senin tanggal 2 November 2020 dan siklus III dilaksanakan pada hari Jumat tanggal 20 November 2020. Dari hasil analisis kesimpulan yang diperoleh dari penelitian ini: Penggunaan metode diskusi dalam pembelajaran Bahasa Indonesia materi pokok teks eksplanasi, terbukti dapat meningkatkan hasil belajar siswa, rata-rata tes formatif pada kondisi awal 55, pada siklus I meningkat menjadi 74,33 , pada siklus II meningkat lagi menjadi 82,5 dan pada siklus III meningkat lagi menjadi 88,63 . Ketuntasan belajar siswa mengalami peningkatan dari kondisi awal 33,33\% meningkat pada siklus I menjadi 50\%, meningkat lagi pada siklus II menjadi 66,67 dan meningkat lagi pada siklus III menjadi 100\%.
\end{abstract}

Kata Kunci: Diskusi, Bahasa Indonesia, hasil belajar.

Social, Humanities, and Education Studies (SHEs): Conference Series https://jurnal.uns.ac.id/shes 


\section{PENDAHULUAN}

Pendidikan merupakan masalah penting dalam memperbaiki Sumber Daya Manusia (SDM). Berbagai upaya telah dilakukan baik oleh pemerintah, lembaga pendidikan, maupun masyarakat untuk meningkatkan kualitas pendidikan. Upaya upaya tersebut antara lain diadakannya inovasi dibidang pendidikan dan pembelajaran. Peningkatan mutu pendidikan akan tercapai jika hasil belajar siswa meningkat. Guru sebagai pengelola pembelajaran mempunyai peran sangat penting dalam meningkatkan hasil belajar siswa. Oleh karena itu dalam setiap kegiatan pembelajaran hendaknya guru dapat menciptakan suasana belajar mengajar yang menyenangkan, dapat mendorong siswa untuk aktif, kreatif dan efisien dalam pencapaian target pembelajaran.

Terkait dengan mutu pendidikan khususnya pada jenjang Sekolah Dasar (SD), berdasarkan pengamatan dan evaluasi hasil belajar Bahasa Indonesia tentang teks eskplanasi siswa kelas VI SD Negeri Danasri Kidul 02 Kecamatan Nusawungu Kabupaten Cilacap masih rendah. Hasil ini dapat dilihat melalui test kondisi awal pada Kompetensi Dasar "Menggali isi teks penjelasan (eksplanasi) ilmiah yang didengar dan dibaca" diperoleh banyak siswa yang mendapat nilai di bawah KKM. Hal ini mendorong penulis untuk mengupayakan dan mencari strategi baru dalam melaksanakan pembelajaran agar siswa dapat mencapai kriteria ketuntasan minimal yang ditentukan.

Ada beberapa hal yang menyebabkan rendahnya nilai hasil belajar siswa, yaitu : (1)Metode pembelajaran yang monoton, guru kurang variatif dalam menyampaikan pembelajaran. (2)Penyampaian pembelajaran kurang bisa mendorong siswa untuk bertanya tentang materi pembelajaran. (3)Sarana dan prasarana masih kurang memadai, baik dari segi jumlah maupun segi kualitas. (4)Suasana pembelajaran lebih bersifat instruksional.

Menghadapi kenyataan tersebut di atas, penulis tertarik untuk mendalami dan melakukan tindakan - tindakan perbaikan pembelajaran Bahasa Indonesia, khususnya materi teks eksplanasi melalui penelitian tindakan kelas. Perbaikan yang penulis lakukan mengenai penerapan metode diskusi pada materi teks eksplanasi. Penulis menggunakan metode diskusi pada penelitian tindakan kelas ini karena metode diskusi dapat mengaktifkan siswa dalam pembelajaran dan meningkatkan hasil belajar siswa.

Metode diskusi adalah cara penyajian pelajaran, di mana siswa-siswa dihadapkan kepada suatu masalah, yang bisa berupa pernyataan atau pertanyaan yang bersifat problematis untuk dibahas dan dipecahkan bersama. (Syaiful Bahri Djamarah dan Aswan Zain : 2006). Metode diskusi adalah suatu cara penyampaian materi pelajaran melalui sarana pertukaran pikiran untuk memecahkan persoalan yang dihadapai (Semiwan, 9990:76).Sedangkan menurut Suryosubroto (1997:179) mengemukakan metode diskusi adalah suatu cara penyajian bahan pengajaran dengan guru memberikan kesempatan kepada siswa atau kelompok-kelompok untuk mengadakan perbincangan ilmiah guna mengumpulkan pendapat, membuat kesimpulan atau menyusun ke berbagai alternatif pemecahan suatu masalah.

Metode diskusi merupakan suatu metode pengajaran yang mana guru memberi suatu persoalan atau masalah kepada murid, dan para murid diberi kesempatan secara bersama-sama untuk memecahkan masalah itu dengan teman-temannya.Dalam diskusi murid dapat mengemukakan pendapat, menyangkal pendapat orang lain, mengajukan usul-usul, dan mengajukan saransaran dalam rangka pemecahan masalah yang ditinjau dari berbagai segi 


\section{METODE}

Penelitian ini merupakan penelitian tindakan kelas (PTK) yang dilaksanakan dalam tiga siklus, setiap siklus terdiri dari tahap perencanaan, pelaksanaan, observasi, dan refleksi. Subjek penelitian ini adalah peserta didik kelas IV SDN Danasri Kidul 02 Nusawungu Cilacap tahun 2020/2021 yang berjumlah 6 peserta didik. Data yang dianalisis berupa data kualitatif yaitu hasil observasi penerapan metode diskusi dan data kuantitatif berupa hasil belajar Bahasa Indonesia peserta didik tentang teks eksplanasi. Teknik pengumpulan data menggunakan tes dan observasi. Alat pengumpul data berupa soal evaluasi dan lembar observasi kegiatan guru dan siswa serta lembar observasi penerapan metode diskusi. Analisis data meliputi reduksi data, penyajian data, dan penarikan kesimpulan.

\section{HASIL DAN PEMBAHASAN}

Berdasarkan hasil diskusi dengan teman sejawat bahwa ketidaktuntasan siswa dalam proses pembelajaran Bahasa Indonesia dengan materi Teks Eksplanasi kelas VI semester I di SD Negeri Danasri Kidul 02, Kecamatan Nusawungu, Kabupaten Cilacap, disebabkan oleh: Siswa kurang konsentrasi dalam pembelajaran, tidak semua siswa terlibat aktif dalam pembelajaran, kurangnya motivasi guru terhadap siswa, kurangnya keberanian siswa dalam mengutarakan pendapat.

Berdasarkan temuan masalah diatas, maka langkah yang ditempuh guru untuk meningkatkan hasil belajar adalah: meningkatkan prestasi belajar siswa dalam pengertian Teks Eksplanasi dengan metode diskusi. Hal tersebut sesuai dengan teori blajar yang dikemukakan oleh J Bruner (1966), bahwa belajar adalah suatu proses aktif yang dilakukan oleh siswa dengan jelas. Untuk meningkatkan kreativitas dan aktivitas dalam melakukan kegiatan pembelajaran, maka pengadaan media pembelajaran harus ditingkatkan dengan cara : memanfaatkan media pembelajaran yang mudah diakses oleh dan menggunakan metode pembelajaran yang tepat.

Menurut C. Roger 1969 : 9 ) dalam teori cooperative learning disebutkan bahwa proses belajar terjadi dengan adanya keterlibatan pribadi, inisiatif diri dan evaluasi diri. Teori ini menimpulkan bahwa belajar harus dilakukan oleh siswa, sedangkan guru hanya sebagai fasilitator. Maka pemilihan metode diskusi sangatlah tepat untuk meningkatkan prestasi belajar siswa, meningkatkan keberanian siswa dalam mengutarakan pandapat melalui metode diskusi.

Metode diskusi akan memberikan kesempatan pada anak untuk memiliki keberanian dalam mengutarakan pendapat. Dalam hal ini diharapkan tutor sebaya mampu membimbing temannya dalam memecahkan masalah. Hal ini sesuai dengan pendapat Siberman $(2000 ; 157)$ bahwa mengajar teman sebaya (per teaching) merupakan salah satu cara untuk mematangkan penguasaan siswa terhadap suatu pelajaran tertentu. Dalam pelaksanaan mengajar teman sebaya, fungsi guru lebih difokuskan sebagai fasilitator dan motivator untuk memberikan penguatan. Hal tersebut sesuai dengan pendapat Brammer (1979;42) yaitu hubungan yang bersifat membantu merupakan upaya guru untuk menciptakan iklim pembelajaran yang kondusif akan terjadinya pemecahan masalah dan pengembangan diri peserta didik. 
Berdasarkan hasil penelitian menunjukkan bahwa hasil belajar Bahasa Indonesia siswa tentang teks eksplanasi mengalami peningkatan. Terlihat dalam tabel berikut ini.

Tabel 1

Hasil Belajar dan Peningkatan Nilai Rata - Rata

\begin{tabular}{|c|c|c|c|c|c|c|c|c|c|}
\hline \multirow[t]{2}{*}{ No } & \multirow[t]{2}{*}{ Ketuntasan } & \multicolumn{2}{|c|}{ Pra Siklus } & \multicolumn{2}{|c|}{ Siklus I } & \multicolumn{2}{|c|}{ Siklus II } & \multicolumn{2}{|c|}{ Siklus III } \\
\hline & & Jumlah & $\%$ & Jumlah & $\%$ & Jumlah & $\%$ & Jumlah & $\%$ \\
\hline 1 & Tuntas & 2 & 33,33 & 3 & 50 & 4 & 66,67 & 6 & 100 \\
\hline 2 & $\begin{array}{l}\text { Belum } \\
\text { Tuntas }\end{array}$ & 4 & 66,67 & 3 & 50 & 2 & 33,33 & 0 & 0 \\
\hline 3 & $\begin{array}{l}\text { Nilai rata - } \\
\text { rata }\end{array}$ & 55 & & 74,33 & & 82, & & 88,6 & \\
\hline
\end{tabular}

Berdasarkan tabel di atas dapat kita lihat bahwa pada Pra Siklus hanya 33,33\% siswa yang meraih ketuntasan, $50 \%$ pada siklus I, pada Siklus II sebanyak $66,67 \%$ dan pada siklus III mencapai $100 \%$. Ini menunjukkan bahwa peningkatan yang signifikan apabila kita menggunakan metode dan cara belajar yang tepat sehingga siswa dapat belajar dengan semangat dan meraih prestasi yang kita harapkan.

Pada nilai rata - rata juga mengalami peningkatan yang signifikan, nilai rata rata pada pembelajaran awal 55 , pada siklus I mengalami peningkatan yaitu 74,33 , pada perbaikan pembelajaran siklus II menjadi 82,5 dan pada siklus III meningkat menjadi 88,63 . Perbaikan pembelajaran cukup pada siklus III tidak perlu dilanjutkan pada siklus berikutnya karena tuntas 6 siswa dari 6 siswa atau $100 \%$.

Dari tabel 1 dari hasil evaluasi pembelajaran awal hingga perbaikan pembelajaran siklus III mata pelajaran Bahasa Indonesia jika disajikan dalam bentuk diagram maka dapat dilihat pada gambar 1 berikut.

\section{Gambar 1. Hasil Belajar}

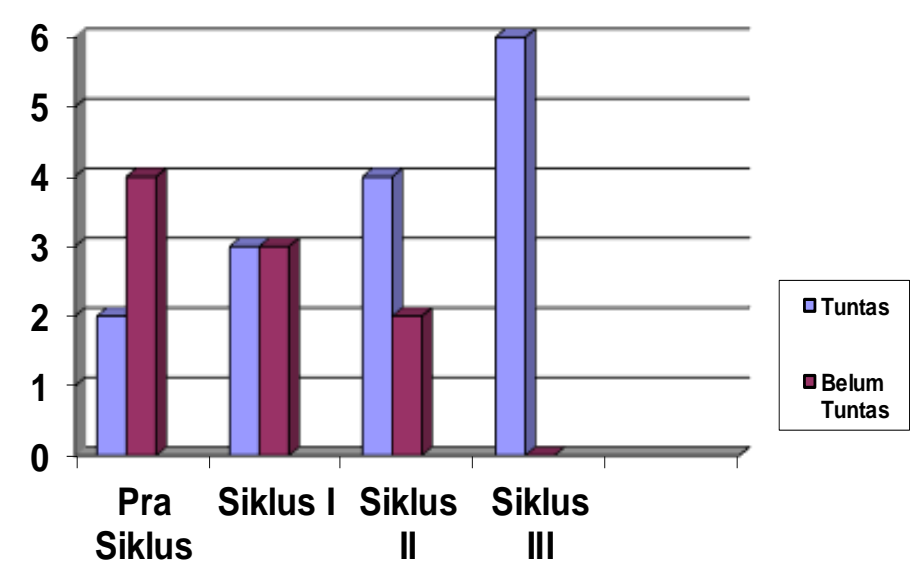


Gambar 2. Peningkatan Nilai Rata-rata

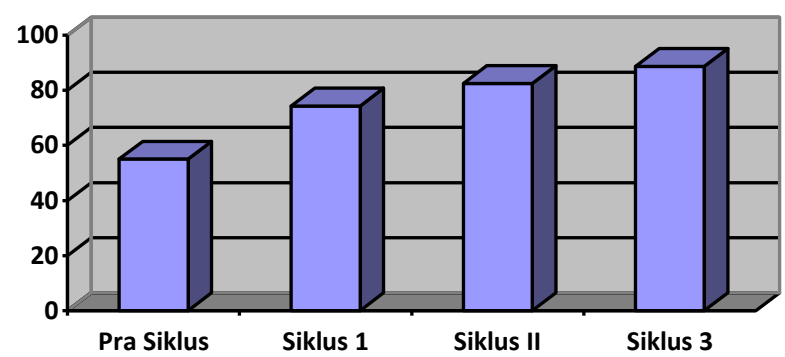

$\square$ Nilai rata-rata

Pada gambar 2 di atas menunjukkan grafik peningkatan nilai rata - rata mata pelajaran Bahasa Indonesia dengan materi Teks Eksplanasi kelas VI semester I di SD Negeri Danasri Kidul 02, Kecamatan Nusawungu, Kabupaten Cilacap, bahwa sebelum perbaikan pembelajaran nilai rata - rata 55 , pada perbaikan siklus I nilai rata - rata 74,33 kenaikan nilai rata - rata 19,33. Pada perbaikan pembelajaran siklus II nilai rata - rata 82,5, kenaikan nilai rata - rata dari perbaikan pembelajaran siklus I ke perbaikan siklus II yaitu 8,17 . Pada perbaikan pembelajaran siklus III nilai rata - rata 88,63 , kenaikan nilai rata - rata dari perbaikan pembelajaran siklus II ke perbaikan siklus III yaitu 6,13 .

\section{SIMPULAN}

Setelah peneliti melaksanakan perbaikan pembelajaran melalui pembelajaran siklus I, siklus II, dan siklus III dengan materi Teks VI semester I tahun pelajaran 2020/2021 di SD Negeri Danasri Kidul 02, Kecamatan Nusawungu, Kabupaten Cilacap, maka peneliti dapat mengambil kesimpulan bahwa upaya meningkatkan hasil belajar siswa dengan metode diskusi telah mampu meningkatkan hasil belajar siswa.

Peningkatan ini terjadi pada siklus I, siklus II maupun siklus III dengan bukti adanya peningkatan pada : menggunakan metode diskusi dapat meningkatkan pemahaman siswa terhadap materi teks eksplanasi, penerapan metode diskusi efektif untuk meningkatkan hasil belajar siswa mata dan pelajaran Bahasa Indonesia tentang teks eksplanasi. Hal ini terbukti dengan meningkatnya hasil belajar siswa yang pada pra siklus ada 2 siswa atau 33,33\% dari 6 siswa yang tuntas dengan nilai rata-rata 55 . Pada perbaikan pembelajaran siklus I meningkat, siswa yang memenuhi kriteria tuntas menjadi 3 siswa atau 50\% dari jumlah 6 siswa dengan nilai rata-rata 74,33, pada perbaikan siklus II menjadi 4 siswa atau $66,67 \%$ dari jumlah 6 siswa dengan nilai ratarata 82,5 dan pada perbaikan siklus III menjadi 6 anak atau $100 \%$ dengan nilai ratarata 88,63 . 
SHEs: Conference Series 3 (3) (2020) 973- 978

DAFTAR PUSTAKA

Arikunto, Suhardjono dan Supardi. 2006. Penelitian Tindakan Kelas. Jakarta: Bumi Aksara.

Aqib, Zainal, dkk. 2011. Penelitian Tindakan Kelas untuk Guru SD, SLB, dan TK. Bandung: Yrama Widya.

Mulyatiningsih, Endang. 2011. Metode Penelitian Terapan Bidang Pendidikan. Bandung: Alfabeta.

Padmono, Y. 2010. Kekurangan dan kelebihan, Manfaat Penerapan PTK. Online: edukasi.kompasiana.com.

Hopkins, David. 1993. A Teacher's Guide to Classroom Research. Philadelphia: Open University Press.

https://www.kajianpustaka.com/2019/03/penelitian-tindakan-kelas-ptk.html

http://ulfiaatm.blogspot.com/2013/06/metode-diskusi.html 